\title{
IN VITRO HEPATOPROTECTIVE ACTIVITY OF YELLOW LEAF EXTRACTS OF THESPESIA POPULNEA AGAINST CARBON TETRACHLORIDE INDUCED TOXICITY
}

\author{
UMADEVI A. , P. AJITH KUMAR \\ Department of Pharmacognosy, Malik Deenar College of Pharmacy, Kasaragod, Kerala, India \\ Email: umanair40@gmail.com
}

Received: 15 Feb 2019, Revised and Accepted: 11 Apr 2019

\begin{abstract}
Objective: The study was aimed to evaluate in vitro hepatoprotective activity of yellow leaf extracts of Thespesiapopulnea.

Methods: Hepatoprotective activity is studied by carbon tetrachloride-induced hepato-toxicity in isolated rat hepatocytes. The biochemical parameters observed in serum were serum glutamate oxaloacetate transaminase (SGOT/AST), serum glutamate pyruvate transaminase
\end{abstract} (SGPT/ALT) levels. The extracts exhibited a dose-dependent reduction in AST, ALT levels.

Results: Methanolic extract was found to exhibit higher hepatoprotection. T. populnea extract was found to be antihepatotoxic at a concentration of 125 mcg with a significant decrease in ALT $(\mathrm{P}<0.001)$ and AST $(\mathrm{P}<0.0001)$.

Conclusion: The results suggest that the methanolic extract has produced significant $(\mathrm{p}<0.001)$ hepatoprotection by decreasing the activity of serum enzymes which is comparable to that of standard drug silymarin

Keywords: Thespesiapopulnea, Methanolic extract, Hepatoprotective activity

(C) 2019 The Authors. Published by Innovare Academic Sciences Pvt Ltd. This is an open-access article under the CC BY license (http://creativecommons.org/licenses/by/4.0/) DOI: http://dx.doi.org/10.22159/ijcpr.2019v11i3.34087

\section{INTRODUCTION}

Hepatic diseases are one of the fatal diseases in the world but today plant-based preparations have a lot to do with the alleviation of hepatic diseases. However, the use of antioxidants has been proposed as therapeutic agents to counteract liver damage [1]. Liver is an aerobic organ which generates reactive oxygen species that induce oxidative tissue damage. These radicals react with cell membranes and induce lipid peroxidation or cause inflammation, which may result as important pathological mediators in many clinical disorders such as heart disease, diabetes, gout and cancer. Reduction of these radicals by antioxidant molecules is crucial to the protection of cells against various disorders. Flavonoids are phenolic compounds widely distributed in plants and have been reported to exert multiple biological effects, including antioxidant and free radical scavenging abilities.

Although, inherent antioxidant systems such as catalase (CAT), superoxide dismutase (SOD) and tissue glutathione (GSH), etc., protect the tissues from free radical attack the excessive release of reactive oxygen species/free radicals overcome this system leading to liver damage. Reinforcing the inbuilt protective antioxidant system or external supplementation of antioxidants may help in protecting the organs [2]. However, conventional drugs do not have satisfactory results in protection of the liver during serious hepatic disorders. In contrast to this herbal drugs are known to have a protective effect against liver damage in various liver disorders. Most of the herbal medicines speed up the natural healing processes of the liver mediated through their antioxidative potential with almost negligible side effects [3].

Thespesiapopulnea (L.), family malvaceae. It is a medium-sized tree with a spreading crown of branches [4]. Leaves are smooth, somewhat similar to those of the Pipal tree, broadly ovate, cordate, acuminate entire, 5-nerved, often with a glandular pore in one or more of the intercostal spaces below. The different parts of the plant have been investigated phytochemically by several workers and found to contain sterols, terpenoids, glycosides and phenolic compounds [5]. The plant has been reported to contain saponins, triterpenes, tannin, saponins, tannins, glycoside, sterols and alkaloids in leaves [6]. The present work is to study the hepatoprotective activity of methanolic extract of
Thespesiapopulnea against $\mathrm{CCl} 4$ induced toxicity using isolated rat hepatocyte.

\section{MATERIALS AND METHODS}

\section{Plant material}

Yellow leaves of Thespesiapopulnea were collected from Kozhikode, Kerala in the month of January 2018. The plant was authenticated by Botanist. Dr. V. S Anil Kumar, Dept. of Botany, Govt. College, Kasaragod, Kerala.

\section{Preparation of extracts}

The coarsely powdered plant material was first defatted with Petroleum ether using soxhlet apparatus. The extract was concentrated using rotary evaporator to get the solid residue. The marc from the central compartment was removed, dried and successively extracted with a series of solvents of increasing polarity with soxhlet extractor was done. Solvents used with increasing polarity are Chloroform, Methanol and Water [7].

\section{Rat hepatocytes culturing and maintenance}

Isolated rat primary hepatocytes were used as in vitro model to evaluate the hepatoprotective activity of the methanolic extract. Fresh isolated rat hepatocytes were collected from Al-Ameen College of Pharmacy, Bangalore, Karnataka and maintained in Dulbecco's modified Eagles medium (DMEM) containing L-glutamine with high glucose [8-10].

Rat hepatocytes were cultured in DMEM medium supplemented with $10 \%$ fetal bovine serum, penicillin (100 U) and streptomycin $(100 \mu \mathrm{g})$, Collaginase Type IV, Insulin 100nM, Hank's Buffer with sodium bicarbonate, EDTA, Calcium chloride, Dexamethasone, Trypan blue, Dipotassium hydrogen phosphate, Sodium chloride,Millipore water. Trypsinisationis the process of using trypsin, a proteolytic enzyme which breaks down proteins to dissociate adherent cells from the Vessels in which they are being cultured. Antibiotics (Streptomycin and penicillin) prevent bacterial contamination. The culture was filter sterilized using $0.2 \mu \mathrm{m}$ pore size cellulose acetate filter. Isolated rat hepatocytes were used for in vitro evaluation of the possible hepatoprotective activity of Chloroform and Methanol extracts of Thespesiapopulnea. 
Hepatoprotective effect of Chloroform and Methanol extracts of Thespesiapopulnea on $\mathrm{CCl} 4$ induced toxicity in rat hepatocytes. Carbon tetrachloride was used to induce hepatotoxicity on rat hepatocytes. The cells were treated with $\mathrm{CCl} 4$ in complete aseptic conditions to induce hepatotoxicity followed by methanolic and chloroform extracts in the concentration such as $5 \mu \mathrm{g}, 25 \mu \mathrm{g}, 125 \mu \mathrm{g} / \mathrm{ml}$. Silymarin was used as standard. The cells were challenged with hepatotoxin $\mathrm{CCl} 4$ and biochemical markers AST and ALT were analysed using ELISA reader. The standard silymarin at a conc. of $25 \mathrm{mcg} / \mathrm{ml}$, different conc. of extracts was tested for their anti-hepatotoxic activity.

\section{Procedure}

Two 96 well flat bottom plates were taken and the experiment was done using 14 wells for each group.

Group I-Negative control (Untreated cell suspension)

Group II-Positive control (CCl4 treated cell suspension)

Group III-Standard I (CCl4 treated cell suspension $+25 \mathrm{mcg} / \mathrm{ml}$ of Silymarin)

Group IV-Extract (CCl4 treated cell suspension $+125 \mathrm{mcg} / \mathrm{ml}$ of $T$. populnea extract)

Group V-Extract (CCl4 treated cell suspension $+25 \mathrm{mcg} / \mathrm{ml}$ of $\mathrm{T}$. populnea extract)

Group VI-Extract $(\mathrm{CCl} 4$ treated cell suspension $+5 \mathrm{mcg} / \mathrm{ml}$ of $\mathrm{T}$. populnea extract)

Flat bottom wells were plated with $50 \mu \mathrm{l}$ of $3.6 \times 106$ cells $/ \mathrm{ml}$. All the wells containing cell suspension except group I were treated with $200 \mu \mathrm{l}$ of $\mathrm{CCl}_{4}$. Wells in group III to VI were treated with $50 \mu \mathrm{l}$ of respective standards, extracts. The plates were incubated at $37^{\circ} \mathrm{C}$ in $\mathrm{CO}_{2}$ incubator for $3 \mathrm{~h}$.

\section{Biochemical analysis}

$20 \mu \mathrm{l}$ of supernatant were taken and added to 96 well microplates for enzyme activity such as alanine transaminase (ALT) and aspartate transaminase (AST) using AST and ALT kit. The reagent was supplied in the kits. The SGOT and SGPT were measured at $340 \mathrm{~nm}$ and expressed as $\mathrm{IU} / \mathrm{l}$. To $20 \mu \mathrm{l}$ of supernatant samples collected after $3 \mathrm{~h}$ treatment, 200 $\mu \mathrm{l}$ of AST reagent was added. The contents were mixed well and read absorbance after 60 seconds in ELISA reader at $340 \mathrm{~nm}$. The procedure was repeated after every 30 seconds up to 120 seconds.

\section{Statistical analysis}

The data are expressed as mean \pm SEM. Statistical analysis was carried out using one-way ANOVA followed byBrown-Forsythe test. $p$ values $<0.05$ are considered as significant.

\section{RESULTS AND DISCUSSION}

Liver is considered to be highly sensitive to toxic agents. $\mathrm{CCl} 4$ administration causes necrosis or membrane damage of liver thereby release of enzymes into the circulation which can be determined by using the serum. The liver damage in Carbon tetra chloride induced hepatotoxin is mainly assessed by determining the serum enzyme levels. CCl4-mediated hepatotoxicity was taken here as the experimental model for liver injury.

In the present study, it was observed that the animals treated with $\mathrm{CCl} 4$ resulted in the significant hepatic damage as shown by the elevated levels of marker enzymes. Here, CCl4 as hepatotoxin and silymarin $(25 \mathrm{mcg} / \mathrm{ml})$ as reference hepatoprotective agents, aspartate transaminase (AST) and alanine transaminase (ALT) were used as markers. The pre-treatment with extract significantly attenuated the elevated levels of the serum markers.

Hepatotoxicity of $\mathrm{CCl}_{4}$ is due to the metabolic formation of the highly reactive trichloromethyl free radical which attacks the polyunsaturated fatty acids of the membrane of the endoplasmic reticulum and initiates a chain reaction leading to the formation of lipid peroxides. The lipid peroxidative degeneration of biomembrane is one of the principle causes of hepatotoxicity of $\mathrm{CCl} 4$ which induces hepatic microsomal enzyme systems and vice versa by antioxidants which mop up the free radicals.

Table 1: Results of biological parameters in T. populnea extract treated groups

\begin{tabular}{llll}
\hline S. No. & Groups & SGOT/AST (IU/l) & SGPT/ALT (IU/l) \\
\hline 1 & Negative control (Cell suspension) & $20.1 \pm 2.75$ & $15.16 \pm 1.701$ \\
2 & Positive control $(\mathrm{CCl})$ & $54.15 \pm 3.7$ & $65.80 \pm 10.32$ \\
3 & Silymarin $(25 \mathrm{mcg} / \mathrm{ml})(\mathrm{std})$ & $32.91 \pm 2.1$ & $16.00 \pm 1.649$ \\
4 & extract $(125 \mathrm{mcg} / \mathrm{ml})$ & $32.94 \pm 2.1$ & $16.93 \pm 2.329$ \\
5 & extract $(25 \mathrm{mcg} / \mathrm{ml})$ & $35.12 \pm 4.1$ & $30.97 \pm 4.077$ \\
6 & extract $(5 \mathrm{mcg} / \mathrm{ml})$ & $42.96 \pm 6.8$ & $48.47 \pm 4.567$ \\
\hline
\end{tabular}

Values are expressed as mean \pm SEM.

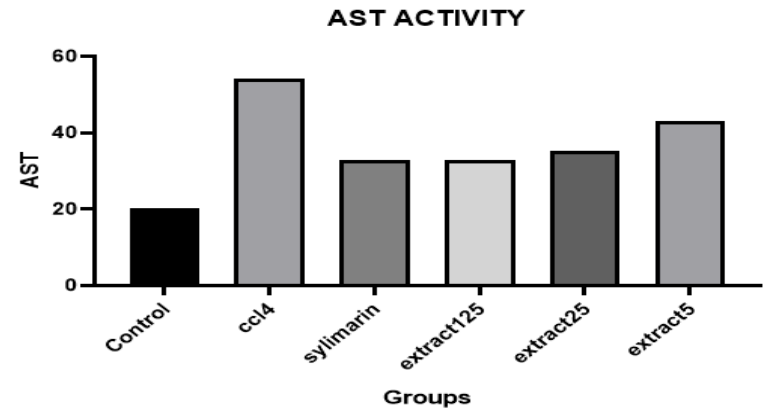

Fig. 1: Effect of Thespesia populnea extract on $\mathrm{CCl} 4$ induced hepatotoxicity on isolated rat hepatocytes (GOT/AST level), ${ }^{* * *} \mathrm{P}<0.0001,{ }^{* *} \mathrm{P}<0.001$, nsP-significant, when compared with CCl4, treated group (one way ANOVA followed by the brownforsythe test

The CCl4 treatment caused a significant $(\mathrm{P}<0.001)$ increase in both the AST and ALT values indicating damage to the hepatic cells. The silymarin treatment caused a significant reduction in the increased AST and ALT values $(\mathrm{P}<0.001$ for ALT and 0.0001 for AST) indicating anti-hepatotoxic activity. T. populnea extract was found to be antihepatotoxic at a conc. of $125 \mathrm{mcg} / \mathrm{ml}$ with a significant decrease in ALT $(\mathrm{P}<0.001)$ and AST $(\mathrm{P}<0.0001)$. These results are encouraging and confirmed the anti-hepatotoxic activity of $T$. Populnea extract.

\section{ALT ACTIVITY}

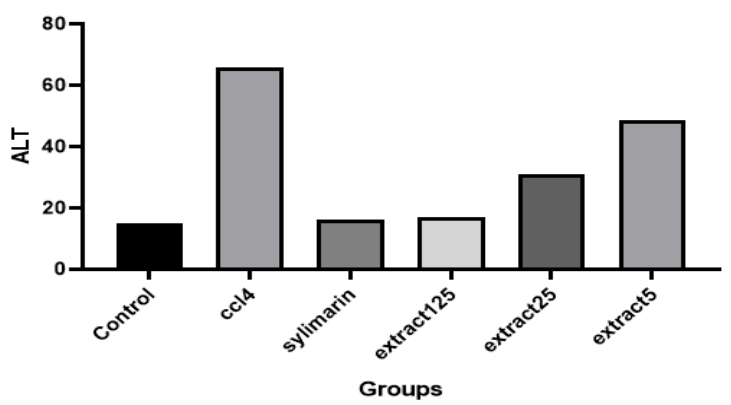

Fig. 2: Effect of Thespesia populnea extract on CCl4 induced hepatotoxicity on isolated rat hepatocytes (GPT/ALT level), ***P $<0.0001, * * \mathbf{P}<0.001$, ns $\mathrm{P}$-significant when compared with $\mathrm{CCl}_{4}$ treated group (one-way ANOVA followed by brown-forsythe test 


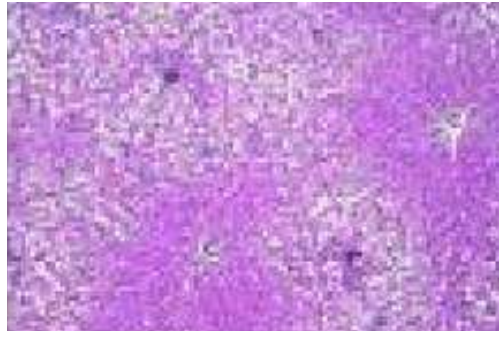

Fig. 3: $\mathrm{ccl}_{4}$ treated group

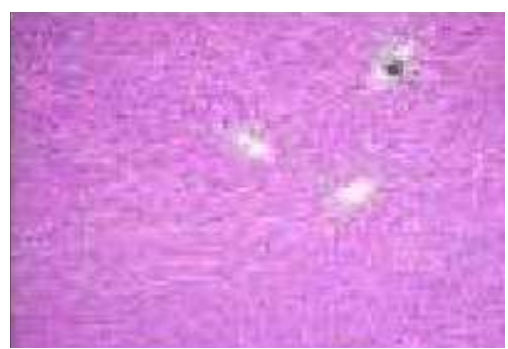

Fig. 4: Sylimarin treated group

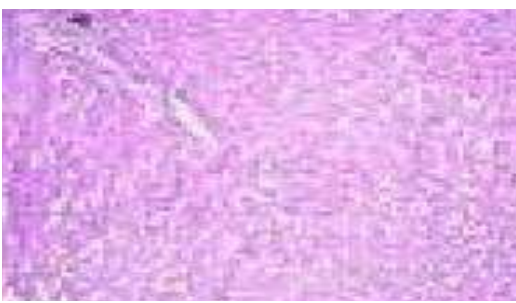

Fig. 5: Extract (5mcg/ml)

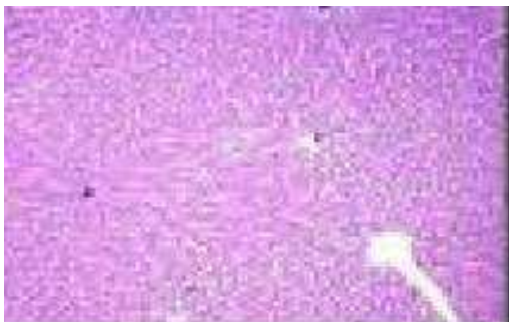

Fig. 6: Extract $(125 \mathrm{mcg} / \mathrm{ml})$

\section{CONCLUSION}

The present study reveals that, hepatoprotective activity of leaf extract of Thespesiapopulnea by in-vitro analysis on rat hepatocytes against CCl4 induced hepatotoxicity was confirmed. Further works are being carried out to isolate and identify the active principle involved in the hepatoprotective activity of plant extracts.

\section{ACKNOWLEDGEMENT}

We are very thankful to respected principal and management of MalikDeenar College of pharmacy, Kerala for their support.

\section{AUTHORS CONTRIBUTIONS}

All the author has contributed equally

\section{CONFLICT OF INTERESTS}

Declared none

\section{REFERENCES}

1. Havarasan R, Vasuldevan M, Anbazhagan S, Venkataraman S, Sridhar SK. Hepatoprotective activity of Thespesia populnea bark extract against carbon tetrachloride-induced liver toxicity in rats. Nat Prod Sci 2003;9:83-6.

2. Nagappa AN, Cheriyan B. Wound healing activity of the aqueous extract of Thespesia populnea fruit. Fitoterapia 2001;72:503-6.

3. Chowdhury SA, Islam J, Mahfujur RM, Mostafizur RM, Rumzhum NN, Sultana R. Cytotoxicity, antimicrobial and antioxidant studies of the different plant parts of Mimosa Pudic. S J Pharm Sci 2008;1:80-4.

4. Jayapriya S, Bagyalakshmi G. Phytochemical screening of Thespecia populanea leaf and flower extracts. IJIRSET 2016;5:3445-50.

5. Shirwaikarkumar A, Krishnan AV, Sreenivasan KK. Chemical investigation and antihepatotoxic activity of Thespesia populnea. Int J Pharmacogn 1995;33:305-10.

6. Chander R. Evaluation of hepatoprotective activity of picroliv from picrorhizakurroa in mastomysnatalensis infected with plasmodium berghei. Int J Med Res 1990;92:34-7.

7. Karan M, Vasisht K, Handa SS. Antihepatotoxic activity of swertiachirata on carbon tetrachloride-induced hepatotoxicity in rats. J Phytotherapy Res PTR 1999;13:24-30.

8. Beena P, Purnima S, Kokilavani RJ. In vitro hepatoprotective activity of ethanolic extract of coldeniaprocumbens Linn. J Pharm Res 2011;3:144-9.

9. Wormser U, Zakine SB, Stivelband E, Eizen O, Nyska A. The liver slice system: A rapid in vitro acute toxicity test for primary screening of hepatotoxic agents. Toxico In Vitro 1990;4:783-9.

10. Jha $\mathrm{M}$, Nema $\mathrm{N}$, Shakya $\mathrm{K}$, Ganesh $\mathrm{N}$, Sharma $\mathrm{V}$. In vitro hepatoprotective activity of Bauhinia variegata. Pharmacologyonline 2009;3:114-8. 